\title{
CONSTRUCTION ANALYSIS OF BOTTOM GILLNET AS AN ALTERNATIVE TO BOTTOM TRAWL IN PEKALONGAN WATERS
}

\author{
Prihatiningsih Retno Tri ${ }^{\star}$, Fitri Aristi Dian Purnama, Saputra Suradi Wijaya \\ Coastal Resources Management Program, Department of Fisheries, \\ Faculty of Fisheries and Marine Sciences, University of Diponegoro, Indonesia \\ *E-mail: retno trip@yahoo.co.id
}

\begin{abstract}
A bottom trawl is a fishing tool that is not recommended by the government to capture demersal fish resources in Pekalongan waters. Therefore, a bottom gillnet is an alternative substitute for bottom trawl fishing gear in catching demersal fish. This study aimed to technically analyze bottom gillnet fishing gear and the composition of its catch in Pekalongan waters. This research was carried out in the waters of Pekalongan in August 2018 with a 3 GT fishing boat. A bottom gillnet is PA Monofilament $0.4 \mathrm{~mm} ; 4$ inch with a specification of upper net length by 30 meters, bottom net length by 42 meters, net height by 35 mesh for one piece of net, and a hanging ratio by 0.41 . With these specifications, bottom gillnet can capture 3 dominant fish species such as Scomberoides commersonnianus, Pomadasys maculatus, and Plicofollis dussumieri where $50 \%$ of the fish are viable to catch.
\end{abstract}

\section{KEY WORDS}

Bottom gillnet, Pekalongan, technical specifications, viable fish.

Pekalongan waters are one of the potential areas for demersal and pelagic fish distribution in Indonesia. According to the fisheries data in Central Java Province in 2017, the fisheries potential in Pekalongan Regency is 23,089 tons consisting of 6,835 tons of pelagic fish and 16,254 tons of demersal fish. Pekalongan waters have enormous potential of demersal fisheries; the total value of demersal fish production has increased from year to year. In 2011, the fisheries production in Pekalongan amounted to 1063,60 tons and in 2017, the total demersal fisheries production in Pekalongan was increased by 16,254 tons.

So far, to exploit demersal fish resources, Pekalongan local fishermen use bottom trawls that are not recommended by the government. With the large potential of demersal fisheries in Pekalongan, it is important to make an effort to sustainably catch the demersal fish in accordance with the Regulation of the Minister of Marine and Fisheries of the Republic of Indonesia number 71/Permen-KP/2016 dated 30 December 2016 concerning Fishing Lines and Placement of Fishing Equipment in the Fisheries Management Areas of the Republic of Indonesia.

With the Regulation of the Minister of Marine and Fisheries of the Republic of Indonesia, a fishing gear that is in accordance with the conditions set by the Government is needed to catch demersal fish. Gillnet is one of the fishing gears recommended by the government to fishermen in Pekalongan Regency. Based on its operation, the net is divided into surface gillnet, mid gillnet, and bottom gillnet (Sjarif, et.al. 2013). Since the target is demersal fish, the bottom gillnet can be used as an alternative substitute for bottom trawl to capture demersal fish in Pekalongan waters. Thus, it is necessary to have a deeper study of bottom gillnet fishing gear both in terms of its design and construction. The purpose of this research is to analyze technically the bottom gillnet fishing gear in Pekalongan waters.

\section{MATERIALS AND METHODS OF RESEARCH}

This study was conducted on August 2018 in Pekalongan waters at a position between S 060 47.873' - S 06 ${ }^{\circ} 49.349^{\prime}$ and E 109 $36.432^{\prime}$ - E 109²41.510' with a depth between 8 - 15 meters. This study used a descriptive research method where all data was obtained by 
making measurements directly in the field using a bottom gillnet and 3GT fishing boat. Here are the technical specifications of the bottom gillnet that is used to catch demersal fish.

Table 1 - Technical specifications of bottom gillnet with PA monofilament $0.4 \mathrm{~mm}, 4$ inches per 1 piece

\begin{tabular}{lll}
\hline No & DESCRIPTION & SIZE \\
\hline A. & Size/Dimension & \\
1 & Upper net length 1 piece & $30 \mathrm{~m}$ \\
2 & Bottom net length 1 piece & $42 \mathrm{~m}$ \\
3 & Net height (mesh) & 35 \\
B. & Net Body & 4 inch / 101,6 mm \\
1. & Mesh Size $(\mathrm{mm})$ & PA Monofilament \\
2. & Net material & 0.40 \\
3. & Thread number & \\
C. & Rigging & Polyethylene (PE) $\varnothing 6 \mathrm{~mm}$ \\
1. & Head rope & Polyethylene (PE) $\varnothing 6 \mathrm{~mm}$ \\
2. & Buoy rope & Polyethylene (PE) $\varnothing 3 \mathrm{~mm}$ \\
3. & Ground rope & Polyethylene (PE) $\varnothing 3 \mathrm{~mm}$ \\
4. & Sinker rope & \\
D. & Buoy & PVC, Y-3H \\
1. & Material/type & 43 \\
2. & Buoy amount & $78 \mathrm{~cm}$ \\
3. & Distance between buoys & \\
E. & Sinker & Lead \\
1. & Material & 256 @ $10 \mathrm{gr}$ \\
2. & Ammount of sinker (ore) & $15 \mathrm{~cm} / 2 \mathrm{mesh}$ \\
3. & Distance between sinker &
\end{tabular}

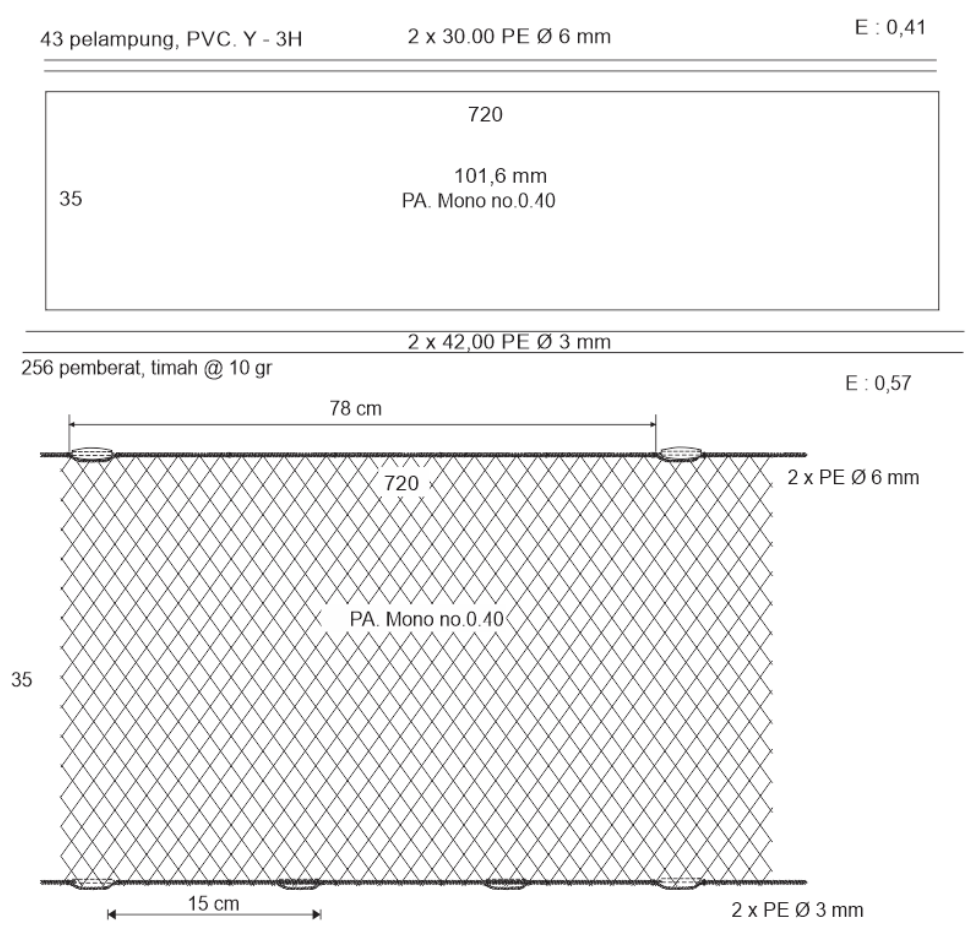

Figure 1 - Design of Bottom Gillnet PA Monofilament $0.4 \mathrm{~mm} ; 4$ inch

To find out the technical criteria for bottom gillnet construction, a technical calculation was carried out. The calculation consisted of hanging ratio (elongation), installed net height, buoyancy, and sinking force as follows (Prado, 1991).

Upper hanging ratio:

$$
E_{L a}=\frac{L_{a}}{L_{0 a}}
$$


Where: $E_{l a}$ - upper hanging ratio; $L_{a}$ - length of installed upper net; $L_{0 a}$ - length of streched upper net.

Bottom hanging ratio:

$$
E_{L b}=\frac{L_{b}}{L_{0 b}}
$$

Where: $E_{1 b}$ - bottom hanging ratio; $L_{b}$ - length of installed bottom net; $L_{0 b}$ - length of streched bottom net.

Upright hanging ratio $\left(E_{2}\right)$ :

$$
E_{2}=\sqrt{1-E_{1}^{2}}
$$

To find out the position of the net in the waters, it can be calculated using formula:

$h=H \sqrt{1-E^{2}}$

Where: $\mathrm{h}$ - height of the installed net; $\mathrm{H}$ - height of stretched ney; $\mathrm{E}$ - average hanging ratio.

The construction of the bottom gillnet has a buoyancy and sinking force so that the net can stretch vertically in the water. The formula below can be used to calculate the buoyancy and sinking force of the net:

$$
B_{1}=W\left(\frac{\partial_{s w}}{\partial_{w}}-1\right)
$$

Where: $B_{1}$ - Buoyancy of the component (kgf); W - Weight of the component in the air (kgf); $\partial_{\mathrm{w}}$ - Mass type of the component $\left(\mathrm{gr} / \mathrm{cm}^{3}\right) ; \partial_{\mathrm{sw}}$ - Sea water density $\left(\mathrm{gr} / \mathrm{cm}^{3}\right)$.

Sinking Force:

$$
S_{1}=W_{n}\left(1-\frac{\partial_{s w}}{\partial_{w}}\right)
$$

Where: $S_{1}$ - Sinking style of the component (kgf); W - Weight of the component in the air/volume $(\mathrm{kgf}) ; \partial_{\mathrm{w}}$ - Mass type of the component $\left(\mathrm{gr} / \mathrm{cm}^{3}\right) ; \partial_{\mathrm{sw}}$ - Sea water density $\left(\mathrm{gr} / \mathrm{cm}^{3}\right)$.

\section{RESULTS AND DISCUSSION}

Gillnet is a fishing gear in the form of rectangular net sheets with the same size of mesh that is equipped with buoys, sinker, and head ropes, with or without ground rope to block the swimming direction of the fish. By that, the target fish will be entangled or twisted in the net (Fachrudin et.al, 2014). Bottom Gillnet is a Gillnet which is operated in the bottom area of the waters to catch demersal fish.

The parts of the bottom gillnet can be described as follows:

- A buoy is an object that has a buoyancy and is installed on the upper net and functions as a float (SNI 01-7220-2008). There are various shape and material of the buoy such as Styrofoam, Poly Vinyl Chloride (PVC), plastic, and etc;

- The buoy rope is a rope that is used to place and tie a buoy (SNI 1-7214-2006);

- Head rope is used to hang the body of the net (SNI 1-7214-2006);

- Upper selvedge, a sheet of net attached to the body of the net that functions as a reinforcement of the upper body of the net;

- Net body, rectangular net sheets with equal or even mesh size; 
- Lower selvedge, a sheet of net installed under the body of the net that functions as a reinforcement of the bottom body of the net;

- Ground rope (gr), a rope that is used to limit the movement of the net to the side;

- Sinker line (sl), a rope that is used to place and tie the sinker;

- Sinker, objects that have sinking power and are installed in the lower net. It functions as a sinker of the net.

To find out the technical criteria for the construction of the bottom gillnet, a technical calculation that includes hanging ratio (elongation), installed net height, buoyancy, and sinking force was made.

The shape of the mesh when operated is determined by the method of hanging the net material on the rope. The length of the net attached to the top is 30 meters while at the bottom net is 42 meters. Moreover, the length of the net stretched is 80 yards (73.52 meters) with the height by $35 \mathrm{MD}$ (1 piece is cut by 2 ).

The calculation for the upper hanging ratio is:

$$
\begin{aligned}
E_{L a} & =\frac{L_{a}}{L_{0 a}} \\
& =\frac{30}{73.15} \\
& =0.41 \\
\mathrm{E}_{(\text {top })} & =0.41
\end{aligned}
$$

The calculation for the bottom hanging ratio is:

$$
\begin{aligned}
E_{L b} & =\frac{L_{b}}{L_{0 b}} \\
& =\frac{42}{73.15} \\
& =0.57
\end{aligned}
$$

The calculation for the upright hanging ratio is $\left(E_{2}\right)$ :

$$
\begin{aligned}
& E_{2}=\sqrt{1-E_{1}^{2}} \\
& =\sqrt{1-0.41^{2}} \\
& =0.91 \\
& \mathrm{E}_{\text {(upright) }}=0.91
\end{aligned}
$$

The height of the net installed in the water can be known, namely:

$$
\begin{aligned}
& \mathrm{H}=\text { height of the net stretched }=35 \mathrm{MD} \times 4 \text { inch }=3,55 \mathrm{~m} \\
& \qquad \begin{aligned}
h & =H \sqrt{1-E^{2}} \\
& =3.55 \times 0.91 \\
& =3.23 \text { meter }
\end{aligned}
\end{aligned}
$$

The construction of gillnet has a buoyancy and sinking force so that the net can stretch vertically in the waters. The calculation of buoyancy and sinking force depends on the density of each component material. If the density of the material is smaller than the density of seawater $\left(1,025 \mathrm{gr} / \mathrm{cm}^{3}\right)$, then the material has a buoyant force (able to float). The gillnet designed is a basic gillnet so that the ratio needed is a smaller buoyancy and larger sinking force. 
Table 2 - The weight of the material in the air and in seawater

\begin{tabular}{lllllll}
\hline No & Element & & Weight in the air $(\mathrm{kg})$ & \multicolumn{2}{l}{ Weight in seawater (Kgf) } \\
\hline 1. & Head rope & PE $\varnothing 6 \mathrm{~mm}$ & $30 \times 0.0169$ & 0.507 & $0.08 \times 0.507$ & 0.040 \\
2. & Buoy rope & PE $\varnothing 6 \mathrm{~mm}$ & $30 \times 0.0169$ & 0.507 & $0.08 \times 0.507$ & 0.040 \\
3. & Ground rope & PE $\varnothing 3 \mathrm{~mm}$ & $42 \times 0.0042$ & 0.177 & $0.08 \times 0.177$ & 0.0142 \\
4. & Sinker rope & PE $\varnothing 3 \mathrm{~mm}$ & $42 \times 0,0042$ & 0.177 & $0.08 \times 0.177$ & 0.0142 \\
5. & Webbing & & & 0.317 & $0.10 \times 0.317$ & 0.032 \\
6. & Buoy & $43 \mathrm{PI}, \mathrm{Y}-3 \mathrm{H}$, buoyancy by $25 \mathrm{grf}$ & $43 \times 25$ & & & 1.075 \\
7. & Sinker & Pb @ 10 gr, 256 bh & $256 \times 10$ & 2.56 & $0.91 \times 2.56$ & 2.330 \\
\hline
\end{tabular}

Table 3 - Buoyancy and Sinking Force

\begin{tabular}{llll}
\hline No. & Element & Buoyancy / Sinking Force (kgf) & Description \\
\hline 1. & Head rope & $0.040(-)$ & $(-)$ : Floating objects \\
2. & Buoy rope & $0.040(-)$ & \\
3. & Ground rope & $0.0142(-)$ & \\
4. & Sinker rope & $0.0142(-)$ & \\
9. & Webbinging objects \\
10. & Buoy & $0,032(+)$ & \\
11. & Sinker & $1.075(-)$ & \\
12. & Total buoyancy & $2.330(+)$ & \\
13. & Total sinking force & $1.143(-)$ & \\
\multicolumn{2}{l}{ Comparison of buoyancy with sinking force $=1.143 \mathrm{kgf:} 2.418 \mathrm{kgf}=1: 2.04$} \\
\hline
\end{tabular}

Table 4 - Technical provision for bottom gillnet

\begin{tabular}{llll}
\hline \multirow{2}{*}{ No } & \multirow{2}{*}{ Component } & Value & \\
\cline { 3 - 4 } & & Calculation & SNI 3 - 2016 Determination \\
\hline 1 & $\mathrm{E}$ & 0.41 & $0.30-0.70$ \\
2 & $\mathrm{Lb} / \mathrm{La}$ & 1.40 & $1.00-1.20$ \\
3 & $\mathrm{H}$ & $3.23 \mathrm{~m}$ & $1 \mathrm{~m}-8 \mathrm{~m}$ \\
4 & $\mathrm{dt}$ & $0.4 \mathrm{~mm}$ & $0.1 \mathrm{~mm}-1.8 \mathrm{~mm}$ \\
5 & $\mathrm{~B} \mathrm{per} \mathrm{La}$ & $38.1 \mathrm{gf} / \mathrm{m}$ & $16 \mathrm{gf} / \mathrm{m}-40 \mathrm{gf} / \mathrm{m}$ \\
6 & SF per Lb & $57.57 \mathrm{gf} / \mathrm{m}$ & $30 \mathrm{gf} / \mathrm{m}-85 \mathrm{gf} / \mathrm{m}$ \\
7 & MS & $101.6 \mathrm{~mm}$ or 4 inch & $25.4-203.3 \mathrm{~mm}$ or $1-8$ inch \\
\hline
\end{tabular}

Based on the table above, it can be seen that PA monofilament bottom gillnet $0.4 \mathrm{~mm}$; 4 inch is in accordance with the technical provisions from SNI 3-2016. The overall technical requirements for PA monofilament bottom gillnet $0.4 \mathrm{~mm} ; 4$ inch is still in the range of SNI 32016: Fishing gear - basic gillnet, except for the length ratio of head rope and ground rope by 1.40. The difference in value occurs because the length of the ground rope is $14 \mathrm{~m}$ longer than the head rope. This is due to the adjustments to the fishing area conditions and the habits of local fishermen to lighten the withdrawal of the net.

From the analysis, it is known that the bottom gillnet performance, in general, can be operated properly. The process of dropping/setting the net takes 5-8 minutes. The buoy on bottom gillnet can work well because it is able to withstand the sinking force of the net. It means that the buoyancy functions properly. This is shown from the condition of the upper net that is not twisted when the hauling of the net took place which then followed by the position of the net sheets that was stretched in the waters. The sinker of bottom gillnet also works well because it is able to compensate the buoyant force so that it can stretch the net sheets in the waters. Besides that, the hanging ratio on bottom gillnet by 0.41 is in accordance with the technical provisions (Prado, 1991) for basic gillnet. Hanging the net with the hanging ratio makes the fish trapped and or twisted on the net. The fish captured are in conformity with the target that is to capture large fish, based on the mesh size of the net that is 4 inches.

Based on the observations, there are several types of fish caught on bottom gillnet. Overall, the fish caught on bottom gillnet can be seen in the following table: 
Table 5 - The Composition of Bottom Gillnet Catch

\begin{tabular}{llll}
\hline No & Species & Amount (fish) & Total weight $(\mathrm{kg})$ \\
\hline 1 & Scomberoides commersonnianus & 172 & 98.68 \\
2 & Pomadasys maculatus & 30 & 19.35 \\
3 & Arius thallassinus & 21 & 13.48 \\
4 & Lutjanus johni & 14 & 6.66 \\
5 & Alectis cilicaris & 11 & 6.54 \\
6 & Eleutheronema tetradactylum & 11 & 2.91 \\
7 & Portunus pelagicus & 13 & 3.67 \\
8 & Psettodes erumeri & 1 & 0.38 \\
9 & Cynoglossus lingua & 2 & 0.20 \\
10 & Saurida tumbil & 4 & 0.38 \\
14 & Plotus canius & 1 & 1.53 \\
15 & Chirocentrus dorab & 3 & 1.52 \\
\hline
\end{tabular}

The target catch of bottom gillnet is demersal fish. On one operational testing of bottom gillnet in Pekalongan waters in August 2018, there were several demersal fish caught including Pomadasys maculatus, Arius thallassinus, Lutjanus johni, Alectis cilicaris, and Eleutheronema tetradactylum. Whereas, Scomberoides commersonnianus is a group of tropical pelagic fish whose habitat is on the coast and offshore reefs (Griffiths, et.al 2005). Therefore, Scomberoides commersonnianus can be caught with a bottom gillnet in Pekalongan waters at a depth of 8-15 meters.

Based on the description above, there are 3 dominant species which were caught with a bottom gillnet, namely Scomberoides commersonnianus, Pomadasys maculatus, and Plicofollis dussumieri.

Table 6 - The size of the fish caught compared to the literature

\begin{tabular}{llllll}
\hline & \multicolumn{5}{c}{ Fork Length $(\mathrm{FL})$} \\
\cline { 2 - 6 } Species & \multicolumn{5}{l}{ Testing } \\
\cline { 2 - 6 } & $\begin{array}{l}\text { Min } \\
\text { Length } \\
(\mathrm{cm})\end{array}$ & $\begin{array}{l}\text { Max } \\
\text { Length } \\
(\mathrm{cm})\end{array}$ & $\begin{array}{l}\text { Common } \\
\text { Length }(\mathrm{cm})\end{array}$ & $\begin{array}{l}\text { Max } \\
\text { Length } \\
(\mathrm{cm})\end{array}$ & $\begin{array}{l}\text { Length at first } \\
\text { maturity/Lm }(\mathrm{cm})\end{array}$ \\
\hline Scomberoides commersonnianus & 30 & 55 & 90 & 120 & 38.5 \\
Pomadasys maculatus & 29 & 34 & 30 & 59.3 & 15 \\
Arius thallassinus & 33 & 45 & 70 & 185 & 36 \\
\hline
\end{tabular}

Source: www.fishbase.org.

The proportion of biologically viable fish is known based on the size of the Fork Length (FL) of first-mature-gonad fish. The size of the catch is needed to determine the length of the first-mature-gonad or Length at First Maturity (Lm). The proportion of biologically viable fish is known by measuring the Fork Length (FL) of the fish and then compared with the Lm in the literature.

Based on the maximum Fork Length (FL) of the fish which were caught on bottom gillnet, the three major species can be said to be viable to catch because it meets the provisions of Lm; $38.5 \mathrm{~cm}$ for mature Scomberoides commersonnianus (the Scomberoides commersonnianus fish caught on bottom gillnet were $55 \mathrm{~cm}$ ); $15 \mathrm{~cm}$ for mature Pomadasys maculatus (the Pomadasys maculatus fish caught on bottom gillnet were $34 \mathrm{~cm}$ ); $36 \mathrm{~cm}$ for mature Arius thallassinus (the Arius thallassinus fish caught on bottom gillnet were $45 \mathrm{~cm}$ ).

Table 8 - The size proportion of bottom gillnet catch

\begin{tabular}{lllllll}
\hline \multirow{2}{*}{ Criteria } & \multicolumn{2}{l}{ Scomberoides commersonnianus } & \multicolumn{2}{l}{ Pomadasys maculatus } & Arius thallassinus \\
\cline { 2 - 7 } & Amount (fish) & $\%$ & Amount (fish) & $\%$ & Amount (fish) & $\%$ \\
\hline$>\mathrm{Lm}$ & 108 & 62.79 & 19 & 63.33 & 13 & 61.91 \\
$<\mathrm{Lm}$ & 64 & 37.21 & 11 & 36.67 & 8 & 38.09 \\
\hline Total & 172 & 100 & 30 & 100 & 21 & 100 \\
\hline
\end{tabular}


Based on the catch proportion of bottom gillnet, the three dominant species caught are viable to catch. $62.79 \%$ of Scomberoides commersonnianus are viable to catch while the other $37.21 \%$ are not. Besides that, $63.33 \%$ of Pomadasys maculatus species as well as $61.91 \%$ of Arius Thorassinus also viable to catch.

\section{CONCLUSION AND SUGGESTIONS}

The technical specifications of bottom gillnet fishing gear with PA Monofilament 0.4 $\mathrm{mm} ; 4$ inches are hanging ratio by 0.41 with head rope and bottom rope length by 1.40 ; the height of the net installed in the waters by 3.10 meters with a ratio of buoyancy per head rope by $38.1 \mathrm{gf} / \mathrm{m}$ and the ratio of sinking force per ground rope by $57.57 \mathrm{gf} / \mathrm{m}$.

The dominant species caught by bottom gillnet are Scomberoides commersonnianus, Pomadasys maculatus, and Arius thallassinus where $50 \%$ of these fish are viable to catch.

Bottom gillnet fishing gear with PA Monofilament $0.4 \mathrm{~mm}$; 4 inches is recommended to be used to catch demersal fish in the waters of Pekalongan with a depth between 8-15 meters in August at a position between S 060 47.873' - S 06 ${ }^{0} 49.349^{\prime}$ and E 109 $36.432^{\prime}-E$ $109^{\circ} 41.510^{\prime}$

\section{REFERENCES}

1. Fachrudin, Hudring. 2014. Identifikasi Jaring Insang (Gillnet). Petunjuk Teknis Perikanan tangkap. Balai Besar Pengembangan Penangkapan IKan. Semarang

2. Prado, J and P.Y Dremiere. 1991. Petunjuk Praktis Bagi Nelayan. Translated from Fisherman's Workbook, FAO. Semarang: BPPI.

3. Sjarief, B; Hudring; Hartoyo, W. 2013. Laporan Pengumpulan Bahan Standar Jaring Insang di PPN Palabuhan Ratu. Semarang: Balai Besar Pengembangan Penangkapan Ikan.

4. SNI 7277.8:2008. Istilah and definisi-Bagian 8: jaring insang. Badan Standarisasi Nasional. 2008.

5. SNI 01-7220-2006. Bentuk baku konstruksijaring insang dasar monofilament bawal putih. Badan Standarisasi Nasional. 2006.

6. SNI 1-7214-2006. Bentuk baku konstruksi Jaring insang dasar monofilament. Badan Standarisasi Nasional. 2006. 